\title{
Digital Capitalism and Coal Mine Workers
}

\author{
Akın Bakioğlu \\ Erzincan Binali Yıldırım University, Erzincan, Turkey, akin.bakioglu@gmail.com
}

\begin{abstract}
One hundred and seventy-five years ago, in his book titled The Condition of the Working Class in England, Engels wrote about the ways in which the mine workers were exploited within the capitalist system. Classical economists believed that with the improvements in technology, capitalism would create egalitarian employment opportunities for everyone. In their opinion, the coal which served as a catalyser for the classical modernization had no place in the age of digital technology. However nowadays, especially in various developing countries such as Turkey, in the production of coal mines, the existing working conditions are the same as the ones that were applicable one hundred and seventy years ago and the exploitation of the labour of the workers continues. Notwithstanding, digital technologies serve for the control of capitalist production instead of the wellbeing of the workers. Coal has always had an important role in the historical continuity and discontinuity periods of capitalism. Considering the unbreakable link between the exploitation of nature and capitalist accumulation of capital, giving up coal and switching to renewable energy sources does not seem possible. The dialectical link between technology consumption and technology production is also one of the most important reasons for coal production to continue. This article argues that in Turkey today, the technology used in coal mine craft prioritises the control of labour rather than prioritizing the working comfort of the mine workers.
\end{abstract}

Keywords: digital capitalism, mine workers, space mining, coal production.

\section{Introduction}

The aim of this paper is to discuss the relationships between digital capitalism and coal mining. Questions to which possible answers should be given are:

- How different is the current period called digital capitalism from the early periods of capitalism?

- How can the relationship between coal production and space technologies be expressed in the context of the exploitation of nature?

- Have technological advancements been effective in preventing mining disasters?

In today's capitalist society, capital accumulation is organised based on living labour despite having gone through many qualitative changes. The capitalist historical formation process has shown that surplus value production needs living labour. Technological developments did not abolish class-based society, nor did they change the capital accumulation process based on the exploitation of living labour. When the machine gradually takes over an industry, wrote Marx, "it creates a chronic misery between the workers who compete with it" (Marx 1867, 557). Indeed, that is the reason why $19^{\text {th }}$ century workers intended to smash the machines that threatened to take away their work, their food and their trade. Machine breaking was an important part of working class hatred in the early ages of mechanisation. 
This process quickly evolved into the obsessive screw-tightening tragedy of the workers in Chaplin's "Modern Times" (Chaplin 1936), as the worker became an extension of the machine. Today, technology controls labour while producing mechanisms that help establishing a tight connection between networks of exploitation. Capital is apparent not in the use-value of commodities, but in their production for profit (Ghosh 2012). The manufacturing process converts productive capital into commodity capital.

The exploitation of nature results in the commodification of natural resources. Human beings have developed tools to influence nature in order to dominate nature and to turn passive resources into commodities (Engels 1925, 462-463). When the efficiency of machines and human labour are compared, it is seen that people's employment areas are shrinking. As a result of the acceleration of technological progress, the development of the service sector has also accelerated, and the employment of unskilled labour has become increasingly difficult. Just like the industrial sector, the service sector has started using machines instead of employing unskilled and semi-skilled labour. The service sector and the industry sector, which needed more skilled labour, supported education and science, relatively increasing the level of education. Technological developments, which are an actor that narrows the employment areas of unskilled and semi-skilled labour, lead to cheaper prices and an increase in production, service quality, and efficiency.

When considered as a factor that led to industrialisation, it is seen that technology has an important place in the evolution of division of labour and specialisation. For example, the increased demand for a female workforce, for which there was less demand than a male workforce before industrialisation, has been due to the easing of labour-intensive working conditions and technological developments. Despite all these developments, we have not yet fully transitioned into a whole new era. Various modes of production and modes of the productive forces co-exist within the contemporary capitalist formation of society (Fuchs 2014, 170). The widespread use of technology has led to an increase in energy consumption. Therefore, the extraction of minerals used in energy production is still important. Although 175 years have passed since Engels wrote about the reality of the working class in England, global capitalism continues to thrive on the extraction of resources from nature.

Although alternative energy resources that can replace coal have been developed in the world since the 1980s and the dissolution of ESCS (European Coal and Steel Community) in Europe has led to significant developments in the global North, coal production retains its importance for developed and developing countries. Currently, $27 \%$ of the world's total energy production is produced from coal sources (Enerdata 2019):

In nine G20 countries, the absolute energy supply from coal increased between 2012 and 2017, mostly mirroring rising economic development in these countries and an overall increase in energy consumption: Indonesia $(+61 \%)$, India $(+26 \%)$, Turkey $(+28 \%)$, Brazil $(+8 \%)$, Mexico $(+7 \%)$, South Korea $(+6 \%)$, Japan $(+6 \%)$, Argentina $(+3 \%)$ and Russia $(+3 \%)$ (Climate Transparency 2019).

This study claims that today, coal production maintains its historical importance from the beginning of industrialization. The study examines social classes within the framework of class war and class experience. As someone who spent his childhood years in a mining town, had many relatives working in coal mines, and studied miners during 
his graduate and doctorate studies, my observations, experiences and personal views are reflected in this work.

\section{Microchips and Coal Production: Exploitation of Nature from the Underground to Space}

According to Engels, all living beings except human beings are passive rather than active in the formation of history (Engels 1925, 460). People make their own history. And with the modification of nature by history (Marx and Engels 1845/1846, 330), humans began their historical activity (Engels 1925, 330). The use of underground mines has an important place in the construction of above-mentioned history. Humans both belong to nature and are historical social beings.

The rational and free individual makes nature the object of their creative activity through their labour. This phenomenon, understood as the objectification of nature by reason, reflects the emergence of property in social terms. It indicates the closing of the distance between the subject and the object in philosophical terms. The epistemological contrast that modern philosophy establishes between subject and object turns into an ontological unity in the social relations of production. While Hegel demonstrated that this transformation is historical, Marx shows that this historical transformation is necessary but not at all human. Therefore, it transforms the subject-object association into a conditional one (Marcuse 2013a, 154). And thus it is not Hegel's theory that transforms the negatively characterised dialectic into a tool of affirmation. Marx's theory is a critique, in the context of all its concepts being an accusation of the whole of the existing order (Marcuse 2013a, 258).

In addition to the production of essential nutrients for life, the energy needed especially in the production of production tools is obtained from natural resources. In the process ranging from cooking and eating food to steam engines and launching rockets into space, all production tools are produced using energy from underground sources.

The link between mining and digital capitalism is evident in Christian Fuchs's (2014) study Digital Labour and Karl Marx. While defining the scope of digital labour, Fuchs $(2014,4)$, defines both the "slave" labour that extracts the materials used in mobile phones or computers from the mines, and the software developers in Silicon Valley or social media users as digital labour. Such workers are all "part of the collective labour force required for the existence, use and application of digital media" (Fuchs 2014, 4) that is organised in the form of an international division of digital labour (Fuchs 2014).

Although this holistic relationship is valid for every period of history, it is a fact that it accelerated with industrialisation. The relationship between the production and consumption of commodities is global and this process has accelerated with the free movement of capital. The rapid development of the western world in science and industry (Daggett 2019, 29), the central role of coal in industrialisation (Mumford 2010, 159) and the steam engines used in production have led to an acceleration in commodity production and the emergence of more workers (Hobsbawm 1999).

Although it is not possible to claim the existence of a uniform proletariat in terms of class culture and consciousness that has influenced the working class all over the world, one can speak of a similar work culture, common all over the world, where the structural conditions of working in coal mines are effective. Underground coal mine work is a sector where labour-intensive labour is especially prominent with very low mechanisation compared to other sectors. Regardless of class culture, a coal miner working in South Africa, China or Turkey is producing coal using similar technological tools. The current reality is quite similar to the working conditions of the miners de- 
scribed by Engels (1845), Orwell (2001) or Zola (2004). Despite using modern production tools, coal mining is much closer to the ancient production style of human struggle against nature due to the working conditions. Today, underground coal mining is in many ways as Engels $(1845,536-537)$ described:

All this deals only with the average of the English coal-mines. But there are many in which the state of things is much worse, those, namely, in which thin seams of coal are worked. The coal would be too expensive if a part of the adjacent sand and clay were removed; so the mine owners permit only the seams to be worked; whereby the passages which elsewhere are four or five feet high and more are here kept so low that to stand upright in them is not to be thought of. The working-man lies on his side and loosens the coal with his pick; resting upon his elbow as a pivot, whence follow inflammations of the joint, and in cases where he is forced to kneel, of the knee also.

Technological progress has not changed the form of exploitation. In May 2014, on the same day when 301 coal miners lost their lives in Turkey due to a mine disaster that took place in a mining town, a biotechnology firm called Deep Knowledge Ventures announced in Hong Kong that they had assigned an artificial intelligence to the board of trustees (Dyer-Witheford 2015). The appointment of an Al boss and the murder of miners taking place on the same day has made class exploitation much more obvious. In addition, despite the six years that have passed since the Soma mining disaster, most of the families of the miners who lost their lives and most of the injured miners have not received the compensation they are legally entitled to, and have organised various protests (a press release in front of the workplace, a march, a sit-in protest, a petition) in 2020 for their compensation.

With the increasing prevalence of renewable energy sources and technological devices that consume much less energy, "old style" energy production such as coal production was expected to come to an end. However, with the rapid development of industrialisation, hard coal, which is a high energy source, maintains its strategic importance today. According to data gathered in $2019,30 \%$ of the energy produced by G20 countries is produced using coal (Climate Transparency 2019, 3).

In an article published in Forbes Magazine in 1999, the following statement was used to emphasize the relationship between coal use and computer technologies: "Dig more coal, the PCs are coming" (Forbes 1999).

Although cognitive capitalism's mode of production is fundamentally based on the collective intellectual labour of people who come together and cooperate in digital networks (Moulier-Boutang 2011, 57) energy production is needed to ensure the conditions necessary for the reproduction of labour. This dialectical relationship may be possible as long as nature is reproduced. This contradiction between capital accumulation and the extraction of resources from nature results in both a crisis of nature and one of capital accumulation.

In the last quarter of the $20^{\text {th }}$ century, it became possible to send people to the planet Mars and establish colonies there. And moreover, a private company having the capital stock (SpaceX) to do this means moving the limits of capital accumulation beyond the world. While allowing access to new natural resources in case the natural resources on Earth are exhausted, it carries capitalism's idea of capital accumulation beyond the planet. 


\section{Miners Not Abiding by the "Rules" vs. "Saviour" Technologies}

Large companies have a cross-border scale organised around multifunctional digital networks. The financial sector invested a remarkable amount of money in information technologies in order to monitor digital network services and quickly changing prices, etc. while also ensuring investment security (Schiller 2011, 925). These investments have increased significantly, especially after 1970. Controlling labour (Baruh 2007; Andrejevic 2007; Cohen 2008) the mechanisation of production and work discipline have been going through a digital siege (Toscano 2007; Vercellone 2007). After all, "capital has an inherent drive and a constant tendency to raise the productivity of labour in order to cheapen commodities and the worker himself through the cheapening of commodities" (Marx 1867, 436). Regulations regarding worker health and safety in underground mining are made with parameters such as groundwater conditions, hazardous gases, fires, explosions, dents, and ventilation in mind (Bennett and Passmore 1984).

In today's mining industry, underground control is achieved by using various technological tools. Underground movements can be monitored by microchips attached to workers' helmets or lamps. Entries and exits to mines are controlled by digital tallymen with iris scanners. These regulations, made to discipline workers who have more control over their labour than their bosses in underground working conditions (Lyon 1994, 55), are imposed with the discourse of "protecting" workers against the "unexpected" risks of underground working conditions.

Fatal accidents still cannot be prevented in today's mining, where worker health and safety practices are digitalized. Considering the amount of informal work in the mining sector, it can be said that death statistics contain serious deficiencies. The existence of many seasonal coal mines operating informally in Zonguldak, Turkey, an area full of coal reserves, is common knowledge. Accidents or deaths of employees in such enterprises are not reflected in official statistics.

The root cause of the catastrophes in coal mines is the selfishness of the bourgeoisie (Engels 1845, 537). Looking at the top 20 of the deadliest mining disasters in the world in the last 50 years, it is seen that 13 of them took place between 2000-2014 (Burton, Ivanova, and Lewis 2019). Again, among the mining disasters that took place in those years, 30 miners lost their lives in Afghanistan in 2019; 301 in Turkey in 2014 , 57 in the Central African Republic, 83 in China-Tibet, and 66 in China in 2013 (Garside 2020). In India, from June 2016 to June 2019, a total of 417 miners died in fatal mine accidents, and 238 of those killed were coal miners (Industrial Global Union 2019). Considering the current state of technology, there is no obstacle to the prevention of fatal mining disasters. However, today just like at the time of Engels investments that would prevent accidents are being neglected in order to generate more profit:

A proper ventilation of the mines by means of fresh air-shafts could almost entirely remove the injurious effects of both these gases. But for this purpose the bourgeoisie has no money to spare, preferring to command the working-men to use the Davy lamp, which is wholly useless because of its dull light, and is, therefore, usually replaced by a candle. If an explosion occurs, the recklessness of the miner is blamed, though the bourgeois might have made the explosion well-nigh impossible by supplying good ventilation. Further, every few days the roof of a working falls in, and buries or mangles the workers employed in it. It is the interest of the bourgeois to have the seams worked out as completely as possible, and hence the accidents of this sort. Then, too, the ropes by which the men descend into the mines are often rotten, and break, so that the unfortunates fall, and are crushed (Engels 1845, 537-538). 
If what class the miracle belongs to and the conditions of that class are not taken into consideration; cheering for technical advancements is futile (Bloch 1995, 241). The domination of technological progress in working life is also a form of class domination. The technological progress in which production has increased but worker safety is ignored makes itself apparent in the mining sector. Accidents associated with machinery in the workplace are portrayed as the fault of the worker or the machine. Technology, on the other hand, is always affirmed. For example, the safe rescue of workers stranded underground in a mine in Chile on August 5, 2010, after 69 days, was possible thanks to technology, but no one seems to be responsible for not taking measures before the accident happened. Technology being portrayed as a saviour has been used to cover up imprudence.

While the working life of today's mine worker is controlled by technology, the technological reality is that technological equipment that will prevent workers from dying or having serious accidents is activated only when production is disrupted. However, the reality is distorted to make it seem that employees who do not obey the rules are responsible for the bad things that happen to them, and that technological control is to protect their health and watch over them.

\section{New Social Movements and the Miners We Know}

Machines or technological elements, which are the visible form of digitalization, are not subjects in themselves. They do not say "we do what living labour does at lower costs" or "we are working to end global exploitation" with their free will. Information and communication technologies (ICT) are tools used to increase the alienation of living labour. The limit of technical evolution for the bourgeois society in which we live is a form of capitalism that has developed all the productive forces it can contain, but has somehow not been destroyed (Marcuse 2013b). To understand society, it is necessary to analyse collective organizations that machines are only a part of (Deleuze 1992,6).

One of the best works that reflect a bottom-up history or class struggle perspective on historical analysis is Eric J. Hobsbawm's (1952) work on machine breakers. In the Communist Manifesto, Marx and Engels $(1848,492)$ emphasise the class conflict aspect of machine-breaking and the aspect of struggle that spans from individual workers to the entire factory and from there to a particular line of business. Engels $(1845,503)$ emphasises that the first resistance by workers as a class against the bourgeoisie in the early industrialisation period was machine breaking:

As a class, they first manifested opposition to the bourgeoisie when they resisted the introduction of machinery at the very beginning of the industrial period. The first inventors, Arkwright and others, were persecuted in this way and their machines destroyed. Later, there took place a number of revolts against machinery, in which the occurrences were almost precisely the same as those of the printers' disturbances in Bohemia in 1844; factories were demolished and machinery destroyed.

Hobsbawm $(1952,63)$ took these evaluations one step further, emphasising that mechanisation increased most during periods when unemployment increased and employees' dignity decreased, and that there were machine-breaking movements against these developments. The workers were carrying out these actions not against mechanisation itself, but against the threats brought by mechanisation. Although Hobsbawm partially admits that the act of machine breaking is not a dominant method of struggle in the exploitation of labour due to industrialisation, he proves that machine breaking 
is effective by giving some examples in favour of the working class from the history of the British working class.

In the age of digital capitalism, discussions of resistance can be grouped under two main headings. The first of these is that the resistance will start from a distinction based on identity differences and the other is that the struggle of the working class will be effective.

History has shown, in a way that contradicts Althusser, that class conflict does not spontaneously arise from a structural determination. In the context of resistance, workers' level of alienation is and what they perceive as exploitation is important.

According to Ollman (1987), class consciousness is the agency of the masses of workers who have class consciousness, rather than an entire body of awareness consisting of certain feelings and thoughts. Class consciousness, to be more precise, is constituted by the interests and demands of individual class members towards their class, their sense of solidarity and opposition to other classes, and striving for a more egalitarian society through the assimilation of the dynamics of capitalist society.

The miners' strikes that took place in various parts of the world between 1970 and 1990, when neoliberal policies began to be implemented, are quite remarkable. The miners' strike of 1977/78, which started in six workplaces in 1977 and lasted about 109 days (Ackermann 1979) in the USA, emerged as the self-defence of the working class against the general attack of the capitalist class (Green and Buhle 1983, 322). In 1977, 35,000 miners took part in a strike in Romania's Jiu Valley, protesting against overtime hours, low wages and the rise in the age of retirement (Kideckel 2004, 45). Although in a different context from the above-mentioned strikes, during the dissolution of the USSR in the same period, there were major miners' strikes in Kuzbass in 1989, and Donbas in 1990 and 1991 (Marples 2013, 31). The Zonguldak strike, started by 48,000 coal miners in Zonguldak, Turkey in November 1990, reached 100,000 participants in January 1991 with the participation of the miners and their families. This strike was one of the biggest acts of resistance against privatisation policies in Turkish working-class history. As a result of this strike, mines were not privatised, but many workers were retired.

The most well-known of these strikes was the British miners' strike in 1984-85 that affected the whole of England. After the oil price shock in 1973, rising inflation and a sharp decline in real wages led to conflict among workers, and although there was a decline in strikes until 1980, they were followed by significant increases in the number of strikes after 1980 (Lyddon 2007, 339). The working class, in particular the miners, were fighting against Margaret Thatcher for their right to work (Leeworthy 2012, 837). The general purpose of these strikes in Britain, including the miners' strikes, was to oppose the state's privatisation policies, their oppressive policies on the unions, and the general policies that were trying to take away the working class' power to resist (Steber 2018, 69).

In the 2000s, compared to the mass strikes of the 1990s, there were generally smaller-scale, workplace-based strikes. Apart from Asturian miners' strike in 2012 (Spain), the South Africa Marikana miners' strike, and the 2019 Harlan County coal miners' protest in the USA, these strikes consisted mostly of small-scale strikes, actions and protests on a local basis in accordance with the spirit of this period.

It is clear that classes are not structures that develop on a regular and consistent line. The class participation of the miners in question continues in the historical process not by proactive but by occasionally interrupted trends, mostly withdrawn from organized class movement and stuck within the framework of daily forms of resistance. 


\section{Conclusion}

Currently, coal production is as important in the processes of capital accumulation as it was in the most active times of the industrial revolution. The primary effect of the age of digital capitalism is the rapid circulation of capital. Thus, the capital acquired as a result of the coal produced is turned into an investment by going back into circulation, even in third world countries. Capitalist processes of capital accumulation organised around living labour grow through the commodification of nature.

Coal mining comprises a basis where we can read both the continuity and the discontinuities in the capitalist mode of production. The fact that coal is still being produced today reveals a continuity in terms of capitalist production strategies and the need for raw materials. At the same time, despite the advanced technological infrastructure, it remains a sector where mining disasters still occur, and where precarious work can be seen in the clearest way due to its working conditions.

Today, we see that the energy obtained from coal maintains its importance in meeting the increasing energy need both in the use and production of technology. It is likely that the energy produced from coal will be used in the process of commodifying "precious metals" found on extra-terrestrial planets that are still not commodified. Coal mining, which stands at the centre of the node between traditional and digital capitalism, is at the centre of capital accumulation processes from earth mining to space mining.

The first steps of space mining have been taken by means of high-tech devices sent to the Moon and Mars and used by people on earth. The fact that the most important steps are taken not through states but through capitalist private enterprises shows that the process of transforming extra-terrestrial nature into a commodity has entered the processes of capitalist capital accumulation.

In the age of digital capitalism, it is seen that technological progress is used for the control of working life rather than worker health safety. The most important indicator of this is that the highest fatal mining disasters in the mining sector took place in the 2000s despite the advanced technological infrastructure. It is clear that in today's coal mining, technology dedicated to control continues to work for capitalists rather than employees.

As a component of the social relations of production, nature lies at the heart of class and power struggles. Despite the capital accumulation processes obtained from the exploitation of nature, which can be associated with every stage of production, coal mine worker movements have an important place in the struggle. Although the coal miners who vigorously resisted against neoliberal policies in the 1990s could not overthrow neoliberal policies, the struggle continues.

\section{References}

Ackermann, John A. 1979. The Impact of the Coal Strike of 1977-1978. ILR Review 32 (2): 175-188.

Andrejevic, Mark. 2007. Surveillance in the Digital Enclosure. The Communication Review 10 (4): 295-317.

Baruh, Lemi. 2007. Read at Your Own Risk: Shrinkage of Privacy and Interactive Media. New Media \& Society 9 (2): 187-211.

Bennett, James D., and David Lynn Passmore. 1984. Correlates of coal mine accidents and injuries: A literature review. Accident Analysis \& Prevention 16 (1): 37-45. https://doi.org/10.1016/0001-4575(84)90004-6

Bloch, Ernst. 1995. The Principle of Hope. Translated by N. Plaice, S. Plaice and P. Knight. Vol. Volume 2. Cambridge, MA: The MIT Press. 
Burton, Melanie, Polina Ivanova, and Barbara Lewis. 2019. Factbox: Vale tailings dam collapse adds to long list of mining disasters. Reuters. https://reut.rs/2MEwi5v

Chaplin, Charlie. 1936. Modern Times. United States.

Climate Transparency. 2019. Managing the Coal Phase-Out - A Comparison of Actions in G20 Countries. Berlin, Germany: Humboldt-Viadrina Governance Platform.

Cohen, Nicole S. 2008. The Valorization of Surveillance: Towards a Political Economy of Facebook. Democratic Communique 22 (1): 5-22.

Daggett, Cara New. 2019. The Birth of Energy: Fossil Fuels, Thermodynamics, and the Politics of Work. Durham, NC: Duke University Press.

Deleuze, Gilles. 1992. Postscript on the Societies of Control. October 59: 3-7.

Dyer-Witheford, Nick. 2015. Cyber-Proletariat: Global Labour in the Digital Vortex. London: Pluto Press.

Enerdata. 2019. Total Energy Production. https://yearbook.enerdata.net/

Engels, Frederick. 1925. Dialectics of Nature. In Marx \& Engels Collected Works (MECW) Volume 25, 311-588. London: Lawrence \& Wishart.

Engels, Friedrich. 1845. The Condition of the Working Class in England. In Marx \& Engels Collected Works (MECW) Volume 4, 295-596. London: Lawrence \& Wishart.

Forbes. 1999. Dig More Coal - the PCs are coming. Forbes, May 30.

Fuchs, Christian. 2014. Digital Labour and Karl Marx. New York: Routledge.

Garside, M. 2020. Number of casualties in mining accidents worldwide 2005-2019. Statista.

Ghosh, Jayati. 2012. Capital. In The Elgar Companion to Marxist Economics, edited by Alfredo Saad-Filho and Marco Boffo, 28-33. Cheltenham: Edward Elgar Publishing.

Green, James, and Paul Buhle. 1983. Holding the Line: Miners' Militancy and the Strike of 1978. In Workers' Struggles, Past and Present, edited by James Green, 321-343. Philadelphia: Temple University Press.

Hobsbawm, Eric J. 1999. Industry and Empire: From 1750 to the Present Day. New York: The New Press.

Hobsbawm, Eric J. 1952. The Machine Breakers. Past \& Present 1: 57-70.

Industrial Global Union. 2019. Four coal miners dead and nine injured in a coal India accident. http://www.industriall-union.org/four-coal-miners-dead-and-nine-injured-in-a-coal-india-accident

Kideckel, David. 2004. Miners and Wives in Romania's Jiu Valley: Perspectives on Postsocialist Class, Gender, and Social Change. Identities 11 (1): 39-63.

Leeworthy, Daryl. 2012. The Secret Life of Us: 1984, the Miners' Strike and the Place of Biography in Writing History "From Below". European Review of History: Revue européenne d'histoire 19 (5): 825-846.

Lyddon, Dave. 2007. From Strike Wave to Strike Drought: The United Kingdom, 1968-2005. In Strikes Around the World, 1968-2005: Case-Studies of 15 Countries, edited by Sjaak van der Velden, Heiner Dribbusch, Dave Lyddon and Kurt Vandaele, 339-365. Amsterdam: Aksant.

Lyon, David. 1994. The Electronic Eye: The Rise of Surveillance Society. Minneapolis: University of Minnesota Press.

Marcuse, Herbert. 2013a. Reason and Revolution. New York: Routledge.

Marcuse, Herbert. 2013b. One-Dimensional Man: Studies in the Ideology of Advanced Industrial Society. New York: Routledge.

Marples, David R. 2013. The Collapse of the Soviet Union 1985-1991. New York: Routledge.

Marx, Karl. 1867. Capital. Volume I. London: Penguin.

Marx, Karl, and Friedrich Engels. 1845/1846. The German Ideology. Critique of Modern German Philosophy According to Its Representatives Feuerbach, B. Bauer and Stirner, and of German Socialism According to Its Various Prophets. In Marx \& Engels Collected Works (MECW) Volume 5, 19-539. London: Lawrence \& Wishart.

Marx, Karl, and Friedrich Engels. 1848. The Manifesto of the Communist Party. In Marx \& Engels Collected Works (MECW) Volume 6, 477-519. London: Lawrence \& Wishart. 
Moulier-Boutang, Yann. 2011. Cognitive Capitalism. Translated by Ed Emery. Cambridge: Polity.

Mumford, Lewis. 2010. Technics and Civilization. Chicago: University of Chicago Press.

Ollman, Bertell. 1987. How to Study Class Consciousness, And Why We Should. Insurgent Sociologist 14 (1): 57-96.

Orwell, George. 2001. The Road to Wigan Pier. London: Penguin.

Schiller, Dan. 2011. Power Under Pressure: Digital Capitalism In Crisis. International Journal of Communication 5: 924-941.

SpaceX. n.d. Starship. Accessed September 13. https://www.spacex.com/vehicles/starship/

Steber, Martina. 2018. Fundamentals at Stake: The Conservatives, Industrial Relations and the Rhetorical Framing of the Miners' Strike in 1984/1985. Contemporary British History 32 (1): 60-77.

Toscano, Alberto. 2007. From Pin Factories to Gold Farmers: Editorial Introduction to a Research Stream on Cognitive Capitalism, Immaterial Labour, and the General Intellect. Historical Materialism: Research in Critical Marxist Theory 15 (1): 3-11.

Vercellone, Carlo. 2007. From Formal Subsumption to General Intellect: Elements for a Marxist Reading of the Thesis of Cognitive Capitalism. Historical Materialism: Research in Critical Marxist Theory 15 (1): 13-36.

Zola, Émile. 2004. Germinal. Translated by Roger Pearson. London: Penguin.

\section{About the Author}

Akın Bakioğlu

Akın Bakioğlu received his PhD degree in Sociology from Ankara University in Turkey in 2019. His PhD work was entitled as "Working Class Formation in Zonguldak Coal Basin". He holds an MA degree in Sociology, from Süleyman Demirel University in Turkey (2011). His MA work was titled "Sociological quality of mine workers: working life and off-job life; an application in the Institution of Coal Mine in Turkey". His research interests are mine workers, industrial sociology, migration studies and labour economics, and industrial relations. 